\title{
Evaluation of Physically Effective Fiber for Distributing Total Mixed Rations in Korea
}

\author{
Byong Tae Jeon ${ }^{1}$, Kyoung Hoon Kim², Myeong Hwa Kim${ }^{1}$, Mi Rae $\mathrm{Oh}^{1}$, Hongliang $\mathrm{Li}^{1}$ and Sang Ho Moon ${ }^{1}$ * \\ ${ }^{1}$ Division of Food Bio Science, College of Biomedical and Health Sciences, Konkuk University, Chungju 380-701, Korea \\ ${ }^{2}$ Nation Institute of Animal Science, RDA, Suwon 440-706, Korea
}

\begin{abstract}
This study was carried out to evaluate the physical characteristics of total mixed rations (TMR) prepared in Korea for improving productive effectiveness of dairy and beef cattle. The 40 samples of commercial TMR for dairy and beef cattle in 6 municipals were collected and analyzed for chemical composition and physical properties. There were significant regional differences $(\mathrm{p}<0.05)$ in dry matter and crude protein contents of TMR for dairy and beef cattle. In roughage value index (RVI), neutral detergent fiber (NDF) content, and physically effective NDF (peNDF) $)_{1.18}$ content, there were no regional differences in TMR for dairy cattle, but there were significant regional differences $(\mathrm{p}<0.05)$ in TMR for beef cattle. Thus the results from this study support that because RVI, NDF content, and peNDF content in TMR for dairy and beef cattle exceeded recommended ranges, a little adjustment in TMR for dairy cattle will be necessary to obtain optimal productivity.
\end{abstract}

(Key words : Neutral detergent fiber, Physically effective fiber, Roughage value index)

\section{I . INTRODUCTION}

Accurate management of nutrition for livestock is very important to promote productivity and reduce cost in animal industry. Recently there were more attentions in importance of proper nutritive management for not only dairy cow but beef cattle which has become more than more high performance. Ruminants require adequate amount of coarsetextured feeds to avoid metabolic disorders and, in the case of dairy cows, reduced milk fat production (Sudweeks et al., 1981). To attain higher performance without any metabolic disorders, animal need adequate dry matter intake and high energy density and proper fiber content in their rations. Therefore, it is needed to evaluate accurately how much portion of fiber in diet does cattle require, because forages and roughage are lower in digestibility and available energy than grains and other concentrate and it is often desirable to reduce fiber to minimum levels in the diet (Mertens, 2002) for high performance dairy cow or beef cattle.

Since total mixed ration (TMR) in beef cattle has been widely used, it is very important to recommend proper fiber content and its physical trait in the TMR. The importance of the physical properties of fiber is well evaluated. The rations for dairy and beef cattle need to be balanced for effective fiber to maintain healthy rumen environment and sustainable production activity. Mertens (1997) defined physically effective neutral detergent fiber (peNDF) as the fraction of neutral detergent fiber (NDF) that stimulated chewing and contribute to a ruminal digesta mat consistency in the rumen. The effective NDF system is based on measurement of forage or feed particle size and NDF content with the objective of accurately predicting chewing response (Grant, 1997). Total mixed rations (TMR) have widely spread in the field of dairy and beef production in Korea. However, less information is available on physical properties of TMR and thus accurate evaluation on physical characteristics of TMR is necessary to improve production effectiveness of dairy and beef cattle. This study was aimed to evaluate accurately physical characteristics of commercially distributing total mixed rations in Korea.

\footnotetext{
* Corresponding author: Sang Ho Moon, School of Food Bio Science, College of Biomedical and Health Sciences, Konkuk University,
} Chungju 380-701, Korea, Tel: 82-43-840-3527, E-mail: moon0204@kku.ac.kr 


\section{П. MATERIALS AND METHODS}

Total of 40 samples of commercial TMR for dairy and beef cattle in 6(7) municipals were collected (Table 1) and analyzed for chemical composition and physical property. The samples were analyzed for dry matter (DM), crude protein, ether extract, crude fiber, and crude ash contents (AOAC, 2007). Neutral detergent fiber (NDF) content was analyzed with method of Van Soest and Wine (1967). Particle size distribution of the samples was determined with Penn State Particle Size (PSPS) separator (Kononoff et al., 2003). Dried samples of $1 \mathrm{~kg}$ were well mixed and separated by particle size. Particle size distribution of the collected TMR samples was determined using the PSPS

Table 1. Samples collected from TMR manufacture companies in 6 municipals

\begin{tabular}{lc}
\hline Region & Samples \\
\hline Chungchongbuk-do & 5 \\
Chungcheongnam-do & 10 \\
Jeollabuk-do & 4 \\
Jeollanam-do & 5 \\
Gyeongsangbuk-do & 9 \\
Gyeonggi-do (Kangwon-do) & 7 \\
\hline
\end{tabular}

containing 3 sieves (19, 8 and $1.18 \mathrm{~mm}$ ) and a pan. After sieving, retained samples over the $1.18 \mathrm{~mm}$ sieve were used for calculation of pef index (0-1) and NDF content. The peNDF content of commercial TMR samples was evaluated with multiplying NDF content by pef index (Mertens, 2002). Roughage value index (RVI) was calculated by Sudweeks's equation (1981). Data were analyzed with GLM procedures and means were compared with Duncan's multiple range test using SAS software (2008). All data were expressed as mean \pm SD.

\section{RESULTS}

There were regional differences in the chemical composition of TMR for dairy and beef cattle (Table 2). The DM of TMR for dairy and beef cattle was significantly higher $(\mathrm{p}<0.05)$ in Chungcheongbuk-do than in other regions. Crude protein content of TMR for dairy cattle was highest $(\mathrm{p}<0.05)$ in Chungcheongbuk-do and lowest $(\mathrm{p}<0.05)$ in Jeollabuk-do. That for beef cattle was highest $(\mathrm{p}<0.05)$ in Jeollanam-do and lowest $(\mathrm{p}<0.05)$ in Chungcheongnam-do. In RVI, NDF content, and peNDF content, there were no significant regional differences in TMR for dairy cattle. But peNDF of TMR for beef cattle

Table 2. The chemical composition of TMR for dairy and beef cattle

\begin{tabular}{|c|c|c|c|c|c|c|}
\hline Region & Animal & $\begin{array}{l}\text { Dry matter } \\
\text { (\% as fed) }\end{array}$ & Crude protein & Ether extract & Crude fiber & Crude ash \\
\hline \multirow{7}{*}{ Dairy } & & & …....................... & ....................... & 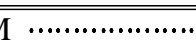 & …...................... \\
\hline & I & $76.85 \pm 11.86^{\mathrm{A}}$ & $17.09 \pm 0.78^{\mathrm{A}}$ & $12.77 \pm 1.93^{\mathrm{B}}$ & $24.20 \pm 5.19^{\mathrm{B}}$ & $7.95 \pm 0.25^{\mathrm{B}}$ \\
\hline & II & $66.56 \pm 9.93^{\mathrm{B}}$ & $15.68 \pm 3.28^{\mathrm{BA}}$ & $12.84 \pm 2.46^{\mathrm{B}}$ & $25.57 \pm 3.66^{\mathrm{B}}$ & $8.92 \pm 1.22^{\mathrm{AB}}$ \\
\hline & III & $70.18 \pm 8.38^{\mathrm{A}}$ & $12.21 \pm 0.52^{\mathrm{C}}$ & $13.57 \pm 2.11^{\mathrm{B}}$ & $33.32 \pm 5.97^{\mathrm{A}}$ & $8.62 \pm 1.46^{\mathrm{AB}}$ \\
\hline & IV & $58.47 \pm 1.36^{\mathrm{B}}$ & $17.15 \pm 0.72^{\mathrm{A}}$ & $12.18 \pm 0.51^{\mathrm{B}}$ & $20.12 \pm 0.74^{\mathrm{B}}$ & $9.61 \pm 0.73^{\mathrm{A}}$ \\
\hline & $\mathrm{V}$ & $56.70 \pm 0.12^{\mathrm{B}}$ & $14.53 \pm 0.06^{\mathrm{B}}$ & $16.19 \pm 0.45^{\mathrm{A}}$ & $24.71 \pm 0.24^{\mathrm{B}}$ & $8.56 \pm 0.11^{\mathrm{AB}}$ \\
\hline & VI & $58.71 \pm 1.84^{\mathrm{B}}$ & $16.08 \pm 1.39^{\mathrm{BA}}$ & $13.32 \pm 1.94^{\mathrm{B}}$ & $23.12 \pm 2.26^{\mathrm{B}}$ & $7.60 \pm 0.70^{\mathrm{C}}$ \\
\hline \multirow{6}{*}{ Beef } & I & $84.09 \pm 1.60^{\mathrm{a}}$ & $13.69 \pm 0.55^{\mathrm{a}}$ & $13.69 \pm 0.26^{\mathrm{a}}$ & $20.89 \pm 4.90^{b}$ & $7.19 \pm 0.21^{\mathrm{c}}$ \\
\hline & II & $71.32 \pm 12.50^{b}$ & $11.78 \pm 2.50^{\mathrm{b}}$ & $11.13 \pm 1.53^{\mathrm{b}}$ & $26.71 \pm 2.82^{\mathrm{a}}$ & $9.31 \pm 2.13^{b}$ \\
\hline & III & $57.86 \pm 3.65^{c}$ & $14.00 \pm 0.56^{\mathrm{a}}$ & $11.23 \pm 1.06^{\mathrm{b}}$ & $14.11 \pm 0.59^{c}$ & $9.85 \pm 0.45^{\mathrm{b}}$ \\
\hline & IV & $67.37 \pm 10.92^{\mathrm{b}}$ & $14.65 \pm 1.69^{\mathrm{a}}$ & $9.37 \pm 5.29^{c}$ & $17.26 \pm 3.58^{c}$ & $9.61 \pm 1.11^{\mathrm{b}}$ \\
\hline & $\mathrm{V}$ & $63.54 \pm 3.07^{\mathrm{C}}$ & $12.91 \pm 1.26^{\mathrm{b}}$ & $14.48 \pm 2.07^{\mathrm{a}}$ & $23.25 \pm 6.10^{\mathrm{a}}$ & $10.97 \pm 2.77^{\mathrm{b}}$ \\
\hline & VI & $58.50 \pm 2.73^{c}$ & $13.50 \pm 1.29^{\mathrm{a}}$ & $8.26 \pm 5.49^{c}$ & $22.74 \pm 3.94^{\mathrm{a}}$ & $13.00 \pm 1.19^{\mathrm{a}}$ \\
\hline
\end{tabular}

Data were expressed as mean $\pm \mathrm{SD}$.

A,B,C Means of dairy cattle with different superscript in the same column are different $(p<0.05)$.

a,b,c,d Means of beef cattle with different superscript in the same column are different $(p<0.05)$.

I : Chungchongbuk-do, I: Chungcheongnam-do, II: Jeollabuk-do, IV: Jeollanam-do, V: Gyeongsangbuk-do, VI: Gyeonggi-do. 
Table 3. Regional comparison in RVI, NDF and peNDF contents of TMR for dairy and beef cattle

\begin{tabular}{cccccc}
\hline Animal & Region & $\mathrm{RVI}^{1}>1.18(\mathrm{~min} / \mathrm{kgDM})$ & $\mathrm{NDF}>1.18(\%)$ & pef $^{2}>1.18$ & peNDF $^{3}>1.18(\%)$ \\
\hline \hline \multirow{5}{*}{ Dairy } & I & $57.68 \pm 0.22^{\mathrm{A}}$ & $70.12 \pm 6.89^{\mathrm{A}}$ & 0.66 & $45.93 \pm 2.84^{\mathrm{B}}$ \\
& II & $57.79 \pm 0.34^{\mathrm{A}}$ & $71.10 \pm 6.40^{\mathrm{A}}$ & 0.63 & $44.97 \pm 5.98^{\mathrm{B}}$ \\
& III & $57.86 \pm 0.13^{\mathrm{A}}$ & $71.46 \pm 2.64^{\mathrm{A}}$ & 0.68 & $48.32 \pm 4.04^{\mathrm{B}}$ \\
& IV & $57.50 \pm 0.08^{\mathrm{A}}$ & $68.59 \pm 7.99^{\mathrm{A}}$ & 0.59 & $40.37 \pm 4.08^{\mathrm{B}}$ \\
& V & $57.72 \pm 0.00^{\mathrm{A}}$ & $70.46 \pm 7.40^{\mathrm{A}}$ & 0.54 & $38.24 \pm 0.00^{\mathrm{B}}$ \\
& VI & $57.88 \pm 0.14^{\mathrm{A}}$ & $71.78 \pm 4.52^{\mathrm{A}}$ & 0.67 & $48.17 \pm 6.55^{\mathrm{A}}$ \\
\hline \multirow{5}{*}{ Beef } & I & $57.88 \pm 0.42^{\mathrm{A}}$ & $71.96 \pm 6.37^{\mathrm{A}}$ & 0.59 & $42.05 \pm 0.01^{\mathrm{B}}$ \\
& II & $58.18 \pm 0.66^{\mathrm{A}}$ & $75.26 \pm 7.89^{\mathrm{A}}$ & 0.69 & $52.39 \pm 14.03^{\mathrm{A}}$ \\
& III & $56.64 \pm 0.50^{\mathrm{B}}$ & $60.75 \pm 3.41^{\mathrm{C}}$ & 0.60 & $36.33 \pm 2.79^{\mathrm{B}}$ \\
& IV & $57.36 \pm 0.35^{\mathrm{BA}}$ & $67.03 \pm 5.73^{\mathrm{B}}$ & 0.61 & $40.70 \pm 0.42^{\mathrm{AB}}$ \\
& V & $57.66 \pm 0.43^{\mathrm{A}}$ & $70.19 \pm 8.50^{\mathrm{AB}}$ & 0.53 & $37.17 \pm 3.74^{\mathrm{B}}$ \\
& VI & $56.64 \pm 0.32^{\mathrm{B}}$ & $60.98 \pm 5.39^{\mathrm{C}}$ & 0.65 & $39.55 \pm 4.24^{\mathrm{AB}}$
\end{tabular}

Data were expressed as mean $\pm \mathrm{SD}$.

${ }^{A, B, C}$ Means of beef cattle with different superscript in the same column are different $(\mathrm{p}<0.05)$.

I : Chungchongbuk-do, П : Chungcheongnam-do, III: Jeollabuk-do, IV: Jeollanam-do, V: Gyeongsangbuk-do, VI: Gyeonggi-do

${ }^{1} \mathrm{RVI}_{>1.18}=10.86+$ Particle size $(\%,>1.18 \mathrm{~mm})-[120 / \mathrm{NDF}(\%)]+\mathrm{NDF}(\%)$,

${ }^{2}$ laboratory assessment $\left(\%\right.$ of $\mathrm{DM}$ retained on a $1.18 \mathrm{~mm}$ sieve) ${ }^{3} \mathrm{peNDF}_{>1.18}=$ pef $\times \mathrm{NDF}(\%)$.

was highest $(\mathrm{p}<0.05)$ in Chungcheongnam-do and lowest $(\mathrm{p}<0.05)$ in Jeollabuk-do (Table 3).

\section{DISCUSSION}

The DM in TMR is a main factor to evaluate proper feed intake and physical property. There were significant regional differences in DM content of TMR. It is thought that difference of production system of TMR, wet type and dry type, is the reason why DM content of TMR differed regionally. Therefore, it will be recommended to choose carefully type of TMR which are more economical and productive benefit to farmers.

Mertens (1997) reported that minimum requirement for peNDF content in lactating dairy cow has been defined as approximately 21 to $23 \%$ of ration DM to maintain ruminal $\mathrm{pH}$ above 6.0 and milk fat above 3.4\% for Holstein cow.

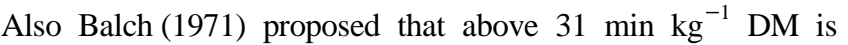
to be necessary to maintain milk fat above $3.5 \%$ in dairy cattle. Although RVI obtained in this study was calculated from laboratory data, RVI and peNDF of TMR produced in all municipals were over the standards proposed by Balch (1971) and Mertens (1997). Therefore, results from analysis generally support that TMR being used in Korea may be adequate in physical characteristic to avoid several metabolic disorders resulting from low roughage intake or NDF concentration.

However, Galyean and Abney (2006) summarized from literature studies that in lactating cows within the range of 22.5 to $45.8 \%$ dietary $\mathrm{NDF}$, intake of $\mathrm{DM}$ and $\mathrm{NE}_{\mathrm{L}}$ intake above maintenance decreased linearly with increasing NDF concentration and in feedlot beef cattle within the range of 7.5 to $35.2 \%$ dietary NDF, DM and NEg intakes increased linearly with increasing NDF concentration and indicated that there was difference between dairy and beef cattle in response to NDF concentration of diets. Thus the results from this study support that because RVI, NDF content, and peNDF content in TMR for both dairy and beef cattle were exceeded reference ranges, a little adjustment in TMR for dairy cattle will be necessary to obtain optimal productivity.

\section{$\mathrm{V}$. ACKNOWLEDGEMENT}

This work was carried out with the support of the "Cooperative Research Program for Agriculture Science and Technology Development (Project No. PJ907038)” Rural Development Administration, Republic of Korea. 


\section{REFERENCES}

AOAC 2007. Official Methods of Analysis. 18th ed, Association of Official Analytical Chemists, Washington, DC, USA.

Balch, C.C. 1971. Proposal to use time spent chewing as an index to which diets for ruminants possess the physical property of fibrousness characteristic of roughage. British Journal of Nutrition. 26:383-392.

Galyean, M.L. and Abney, C.S. 2006. Assessing roughage value in diets of high-producing cattle. Proceedings of the 21st Annual Southwest Nutrition and Management Conference. pp. 127-144.

Grant, R.J. 1997. Interactions among forages and nonforage fiber sources. Journal of Dairy Science. 80:1438-1446.

Kononoff, P.J., Heinrichs, A.J. and Buckmaster, D.R. 2003.

Modification of the Penn State forage and total mixed ration particle separator and the effects of moisture content on its measurements. Journal of Dairy Science. 86:1858-1863.

Mertens, D.R. 1997. Creating a system for meeting the fiber requirements of dairy cattle. Journal of Dairy Science. 80:14631482.

Mertens, D.R. 2002. Measuring fiber and its effectiveness in ruminant diets. Proceedings Plains Nutrition Council Symposium. pp. 40-66.

SAS. 2008. SAS/STAT Software for PC. Release 9.2, SAS Institute Inc. Cary. NC. USA.

Sudweeks, E.M., Ely, L.O., Mertens, D.R. and Sisk, L.R. 1981. Assessing minimum amounts and form of roughages in ruminants diets: roughage value index system. Journal of Animal Science. 53: 1406-1411.

Van Soest, P.J. and Wine, R.H. 1967. Use of detergents in analysis of fibrous feeds. IV. Determination of plant cell-wall constituents. Journal of the Association of Official Analytical Chemists. 50:50-55.

(Received May 24, 2013 / Revised August 17, 2013 / Accepted August 20, 2013) 